\title{
ANALISIS JARINGAN SOSIAL PASAR SUNDAY MORNING (SUNMOR) DI UNIVERSITAS GADJAH MADA YOGYAKARTA
}

\author{
Mona Erythrea Nur Islami, M.A \\ Email : mona_erythrea@yahoo.com \\ Sekolah Tinggi Pariwisata AMPTA Yogyakarta \\ NIDN : 0516097101
}

\begin{abstract}
Sunday Morning market is a weekly market that is open on Sundays morning at Gadjah Mada University area. It is a place for informal traders to sell their goods. The analysis shows that there are some patterns of social networks between traders, suppliers and buyers in Sunday Morning market.

The formation of social networks among traders is a horizontal network, based on kinship ar friendship. They have the same resources and obligations to be exchanged. The social relationship itself will be manifested in help each others. The social networks formed through kinship has important role to overcome social pressures, poverty, unemployment and limited access in getting economic resources. It is common in the informal trading sector, traditional management applied based on friendship, kinship or origin.

The formation of social networks between traders and suppliers is such a vertical social networks, by which the socio-economic status is not worth, as well the exchanged of obligations and resources.The relation between them is patron-client relationship.

Whereas, social networks between sellers and buyers is based on the network of interest, social networks between sellers and buyers based on the network of interest in each other.
\end{abstract}

Keywords : patterns of social networks, traders, suppliers, buyers, Sunday Morning market

\section{PENDAHULUAN}

Kota sebagai pusat perekonomian yang selalu dicirikan dengan industrialisasi tidak selalu ramah kepada masyarakat didalam usaha mencari nafkah untuk memenuhi kebutuhan hidupnya. Industrialisasi dalam proses produksinya menggunakan teknologi yang relatif canggih dan padat modal. Bagi sebagian orang yang mempunyai keahlian dan modal tidak mengalami kesulitan dalam mencari pekerjaan di sektor formal yang padat modal tersebut. Namun karena proses produksi di sektor ini memerlukan modal yang relatif besar dan canggih maka daya serap kesempatan kerja tidak dapat optimal.
Sehingga sektor formal dianggap tidak mampu menyediakan lapangan kerja bagi seluruh lapisan masyarakat, apalagi mereka yang berada pada posisi marjinal.

Krisis ekonomi, pengangguran, terbatasnya lapangan pekerjaan di sektor formal, munculnya kantong-kantong kemiskinan telah membuat masyarakat mencari sumber penghidupan alternatif yaitu sektor informal. Sektor informal dianggap sebagai penyelamat kehidupan, dimana mampu menyediakan pekerjaan dan penghasilan dengan kepemilikan atas modal, keahlian dan ketrampilan yang terbatas atau minim. Hidayat dalam Hartati (2012 : 202) mengemukakan karakteristik 
yang biasa dijumpai dalam sektor informal adalah: 1) kegiatan usaha tidak terorganisasi dengan baik, karena timbulnya unit usaha tidak mempergunakan fasilitas atau kelembagaan yang tersedia di sektor formal; 2) pada umumnya unit usaha tidak mempunyai izin usaha; 3) pola kegiatan usaha tidak beraturan dalam arti lokasi maupun jam kerja; 4) pada umumnya kebijakan pemerintah untuk membantu golongan ekonomi lemah tidak sampai ke sektor ini; 5) unit usaha mudah keluar masuk dari sub sektor ke sub sektor lain; 6) teknologi yang bersifat tradisional; 7) modal dan perputaran usaha relatif kecil, sehingga skala operasi juga relatif kecil; 8) untuk menjalankan usaha tidak diperlukan pendidikan formal, karena pendidikan yang diperlukan diperoleh sambil bekerja; 9) pada umumnya unit usaha termasuk golongan yang mengerjakan sendiri usahanya dan kalau mengerjakan, buruh berasal dari keluarga; 10) modal usaha pada umumnya berasal dari tabungan sendiri atau dari lembaga keuangan yang tidak resmi, dan; 11) hasil produksi atau jasa terutama dikonsumsi oleh golongan kota atau desa yang berpenghasilan rendah tetapi kadang-kadang juga yang berpenghasilan menengah.

Menurut data Survei Angkatan Kerja Nasional (Sakernas) tahun 2015 dari BPS, jumlah angkatan kerja di Indonesia pada bulan februari 2015 mencapai 128,30 juta orang, bertambah sekitar 6,43 juta orang (5,27 persen) dibandingkan angkatan kerja pada bulan Agustus 2014 sebesar 121,87 juta orang. Yang patut mendapatkan perhatian adalah tingkat pengangguran terbuka sebesar 5,81\% pada Februari 2015 mengalami penurunan sebesar $5,94 \%$ dibanding tingkat pengangguran terbuka pada Agustus 2014 (BPS, 2015). Hal ini dipandang sebagai hal yang menggembirakan oleh pemerintah, karena dengan turunnya jumlah pengangguran akan berpengaruh juga pada turunnya tingkat kemiskinan masyarakat.

Di tengah penurunan tersebut, persentase penduduk bekerja di sektor formal berkurang dari $42,06 \%$ menjadi $41,72 \%$. Sementara itu, sektor informal masih mendominasi dengan pergerakan naik dari 57,94\% menjadi 58,28\% (Bisnis com, 2016). Hal ini akan menjadi data yang menarik untuk dipelajari mengingat bahwa sektor informal mampu menyerap tenaga kerja dibandingkan dengan sektor formal. Artinya bahwa masih banyak peluang yang bisa digunakan baik oleh masyarakat atau pemerintah untuk mengembangkannya.

\section{LITERATUR REVIEW}

\section{Pasar Tiban 'Sunday Morning' (Sunmor)}

Pasar tiban Sunday Morning atau orang-orang Jogja biasa menyebutnya dengan pasar 'Sunmor'. Nama yang tidak sesuai dengan ejaan bahasa Indonesia yang disempurnakan tapi begitulah orang-orang Jogja sudah mengenalnya dan keberadaan pasar ini 'ngrejekeni', begitu orang Jawa bilang. Karena ketika para pedagang berjualan di pasar 'Sunmor' bisa meraup keuntungan dua kali lipat dibandingkan hari-hari biasa mereka berjualan. Keuntungan yang bisa diperoleh para pedagang ketika berjualan di pasar ini berkisar antara Rp 30.000 sampai Rp 2.000.000 dalam jangka waktu 6 jam. Pasar Sunday Morning mulai buka pada jam 06.00 pagi sampai sekitar jam 12.00 siang. Uniknya pasar ini hanya buka pada hari minggu dan tempat berjualan para pedagang bukan tempat yang permanen. Pedagang pasar 'Sunmor' terbagi dalam kapling-kapling atau blok-blok dengan menggunakan tenda bongkar pasang. Oleh karena itu disebut pasar tiban Sunday 
Morning. Namun ketika pasar ini digelar akan selalu dipenuhi oleh pengunjung baik yang akan membeli barang atau sekedar melihat-lihat atau hanya sekedar untuk makan.

Latar belakang didirikanya pasar tiban Sunday Morning(Sunmor)dilandasi oleh keinginan UGM untuk membantu masyarakat yang mengalami kesulitan ekonomi pada saat terjadinya krisis ekonomi tahun 1998. Pada saat itu kawasan boulevard yang merupakan bagian dari kawasan UGM disediakan untuk para pedagang yang ingin berjualan dengan syarat tidak mengganggu kelancaran jalannya kegiatan akademik. Pengelolaan pasar tiban Sunday Morning berada dibawah pengawasan DPPA UGM, dalam hal ini struktur dibawahnya ditangani oleh sub direktorat K4P ( Keselamatan Kesehatan Kerja Ketertiban Lingkungan dan Pengelolaan Parkir). Seiring dengan pulihnya keadaan perekonomian dan untuk menjaga kebersihan lingkungan serta menertibkan pedagang, maka lokasi pasar 'Sunmor' dipindahkan ke jalan Notonegoro. Pemindahan lokasi ini disertai dengan pendataan ulang pedagang yang berjualan di situ. Aturan-aturan baru pun dibuat demi keberlanjutan pasar. Aturan-aturan tersebut antara lain : 1) Pedagang yang menempati lokasi di jalan Notonegoro diutamakan pedagang yang dulu berjualan di sepanjang boulevard. Pedagang yang baru boleh mendaftar jika semua pedagang pindahan ini sudah mendapat tempat untuk berdagang (lapak); 2) Lokasi berdagang sesuai dengan yang tercantum di kontrak perjanjian per tahun antara pedagang dengan UGM; 3) Ketentuan harga sewa kavling per bulan adalah : kavling 2 x 10m = Rp 60.000; kavling 2 x 4m = Rp 40.000; kavling $2 \times$ $2 \mathrm{~m}=\mathrm{Rp} 20.000$; gerobak dorong $=\mathrm{Rp}$ 12.000, sedangkan jika ada event-event tertentu harga sewa sudah berbeda; 4) Tidak boleh mengganggu lingkungan UGM, tidak boleh merusak tanaman, tidak boleh mengganggu ketertiban lingkungan.

Demi membantu pihak pengelola agar kerjasama antara pedagang dan UGM berjalan baik, UGM menghendaki dibentuk paguyuban-paguyuban. Ada empat paguyuban yang mewakili UGM untuk mengelola para pedagang di pasar 'Sunmor' ini. Paguyuban-paguyuban tersebut adalah Paguyuban Fajar Wiradigama, Paguyuban Sinar Pagi, Paguyuban Notonegoro, Paguyuban Pedagang Taman Kupu-kupu (P2TKP). Paguyuban yang pertama kali berdiri pada tanggal 7 Desember 1998 adalah Paguyuban Fajar Wiradigama. Tujuan didirikannya paguyuban ini adalah menggalang rasa kemitraan dan keguyuban di kalangan pengusaha warung lesehan khusus minggu pagi di kampus UGM. Untuk membangun citra yang positif bahwa warung lesehan khusus minggu pagi di kampus UGM bukan merupakan usaha yang liar melainkan terorganisir. Anggota paguyuban pada awalnya berjumlah 51 orang, namun saat ini berkurang menjadi 39 orang karena pemindahan tempat dari boulevard ke dekat bundaran kecil. Paguyuban kedua yang terbentuk pada tahun 2002 adalah Paguyuban Notonegoro. Paguyuban ini beranggotakan para pedagang yang berjualan di sepanjang Jalan Notonegoro. Tujuan dibentuknya paguyuban ini adalah untuk mengkoordinir para pedagang yang dulu berjualan di boulevard kemudian pindah di jalan Notonegoro ini. Anggota paguyuban ini berjumlah sekitar 200-an pedagang. Paguyuban ketiga yang didirikan adalah Paguyuban Sinar Pagi. Paguyuban ini berdiri pada tahun 2008 yang digunakan sebagai wadah untuk mengkoordinir para pedagang serta untuk menampung dan 
menyampaikan aspirasi mereka, baik aspirasi yang berupa kritik, saran, keluhan pada pihak pengelola. Anggota paguyuban berjumlah sekitar 200-an pedagang. Paguyuban yang terakhir terbentuk pada tahun 2009 adalah Paguyuban Pedagang Taman Kupu-kupu (P2TKP). Paguyuban ini terbentuk untuk mengkoordinir para pedagang baru yang ingin berjualan di pasar 'Sunmor'. Namun pada tahun 2012 tidak ada lagi penambahan anggota baru karena banyaknya jumlah pedagang. Pada tahun 2012 jumlah pedagang di pasar 'Sunmor' sudah mencapai 600-an pedagang.

Persyaratan untuk menjadi anggota salah satu paguyuban adalah membawa fotokopi KTP, KK dan membayar uang kontrak sesuai dengan kesepakatan dengan pihak pengelola. Jika ada pelanggaran maka pihak pengelola akan memberi sanksi baik berupa teguran, peringatan atau bahkan pemutusan kontrak kerjasama.Tiap kali pasar 'Sunmor' digelar, ada koordinator lapangan dari masing-masing paguyuban yang ditugaskan untuk memantau situasi pasar, menarik uang kebersihan dan memberitahukan kepada masing-masing anggota jika ada event-event tertentu sehingga pasar akan diliburkan pada saat event berlangsung.

Keberadaan pasar tiban 'Sunday Morning' telah memberikan peluang kepada para pedagang untuk mencari penghidupan. Lambat laun pasar tiban ini menjadi semakin terkenal dan justru menjadi tempat berwisata kuliner maupun belanja. Menarik untuk dilihat kemudian bagaimana keberadaan pasar tiban 'Sunday Morning' ini telah membentuk suatu jaringan sistem ekonomi yang saling menguntungkan. Oleh karena itu pertanyaan yang ingin diajukan adalah :
1. Bagaimana jaringan sosial terbentuk antara para pedagang, antara pedagang dan pemasok barang, antara pedagang dan pembeli serta pedagang dan paguyuban?

2. Norma apayang berlaku didalam jaringan sosial yang terbentuk?

\section{Pendekatan Jaringan Sosial}

Pembentukan jaringan sosial merupakan salah satu pendekatan dalam studi antropologi yang berupaya memahami bentuk dan fungsi hubungan-hubungan sosial dalam masyarakat yang kompleks. Mitchell(1969 : 1-2) mengemukakan bahwa jaringan sosial merupakan seperangkat hubungan khusus atau spesifik yang terbentuk diantara sekelompok orang. Karakteristik hubungan tersebut dapat digunakan sebagai alat untuk menginterpretasi motif-motif perilaku sosial dari orang-orang yang terlibat didalamnya. Dalam kenyataan kehidupan, jaringan sosial sedemikian kompleks dan saling tumpang tindih atau saling memotong satu sama lain. Sehingga Bannes (dalam Tri Joko, 2007) membedakan jaringan sosial menjadi jaringan sosial menyeluruh dan jaringan sosial parsial. Jaringan sosial menyeluruh adalah keseluruhan jaringan yang dimiliki individu-individu dan mencakup berbagai konteks atau bidang kehidupan dalam masyarakat. Jaringan sosial parsial adalah jaringan yang dimiliki individu-individu terbatas pada bidang-bidang kehidupan tertentu, misalnya jaringan ekonomi, politik, keagamaan, kekerabatan.

Dalam kehidupan masyarakat yang kompleks, khususnya masyarakat perkotaan, dijumpaiadanya tiga jenis keteraturan hubungan-hubungan sosial, yaitu: (1) keteraturan struktural(structural order), di mana perilaku orang-orang ditafsirkan dalam istilah-istilah tindakan 
yangsesuai dengan posisi yang diduduki dalam seperangkat tatanan posisi -posisi, seperti dalam suatuperusahaan, keluarga, partai politik; (2) keteraturan kategorikal (categorical order), di manaperilakuperilaku orang dalam situasi tidak terstruktur yang dapat ditafsirkan dengan istilahstereotipe seperti kelas, ras, dan kesukubangsan; (3) keteraturan personal (personal order), dimana perilaku orangorang baik dalam situasi-situasi terstruktur atau tidak terstruktur dapatditafsirkan dalam istilah hubungan-hubungan antar individu dalam suatu kelompok atauhubungan antara suatu kelompok dengan kelompok lain (Mitchell, 1969 : $10)$.

Ditinjau dari tujuan hubungan sosial yang membentuk jaringan sosial, dapat dibedakanmenjadi tiga jenis. Pertama, jaringan kekuasaan (power), merupakan hubungan-hubungan sosialyang membentuknya bermuatan kekuasaan. Dalam jaringan kekuasaan, konfigurasi salingketerkaitan antar-pelaku di dalamnya disengaja atau diatur. Tipe jaringan ini muncul bilapencapaian tujuan-tujuan yang telah ditargetkan membutuhkan tindakan kolektif dan konfigurasiyang saling keterhubungan antar pelaku biasanya bersifat permanen. Kedua, jaringan kepentingan(interest), merupakan jaringan di mana hubungan-hubungan sosial yang membentuknya bermuatan kepentingan. Jaringan kepentingan ini terbentuk oleh hubungan-hubungan yangbermakna pada tujuan-tujuan tertentu atau khusus. Struktur yang muncul dari tipe jaringan sosial ini adalah sebentar dan berubah -ubah. Ketiga, jaringan perasaan (sentiment), merupakanjaringan yang terbentuk atas dasar muatan perasaan, di mana hubungan hubungan sosial itusendiri menjadi tujuan dan tindakan sosial. Struktur yang dibentuk oleh hubungan -hubunganperasaan ini cenderung mantap dan permanen. Hubungan sosial yang terwujud biasanyacenderung menjadi hubungan dekat dan kontinyu. Di antara para pelaku cenderung menyukaiatau tidak menyukai pelaku-pelaku lain dalam jaringan sosial. Oleh karena itu muncul adanyasaling kontrol yang relatif kuat antar -pelaku (Kusnadi dalam Herti Gusmiarti, 2008 : 17).

Dilihat dari status sosial ekonomi individu yang terlibat, terdapat dua jenis jaringan sosial,yaitu jaringan sosial horizontal dan vertikal. Jaringan sosial dikatakan bersifat horizontal jikaindividuindividu yang terlibat didalamnya memiliki status sosial ekonomi yang relatif sama.Mereka memiliki kewajiban yang sama dalam perolehan sumber daya, dan sumber daya yangdipertukarkan juga relatif sama. Sebaliknya dalam jaringan sosial yang bersifat vertikal, individu -individu yang terlibat didalamnya tidak memiliki status sosial ekonomi yang sepadan, kewajiban dan sumber daya yang dipertukarkan juga tidak sepadan. Hubungan sosial yang terwujud dalam bentuk hubungan patron klien.

Studi yang dilakukan Saifuddin (dalam Tri Joko, 2007: 5), telah mengidentifikasi hubungan-hubungan sosialyang kontinyu di antara anggota anggota rumah tangga miskin atau antara mereka dengan pihaklain yang memiliki tingkat sosial ekonomi yang lebih tinggi, baik yang berasal dari dalam ataudari luar masyarakat yang bersangkutan. Kemampuan penduduk miskin melakukan seleksi ataspotensi sosial budaya untuk lingkungan hidup di daerah perkotaan menjadikan merekamenciptakan dan memelihara jaringan sosial, baik untuk mereka yang memiliki stuatus 
ekonomisetara maupun berbeda. Sarana terpenting untuk hal tersebut adalah jaringan kekerabatan,ketetanggaan, pertemanan, dan kesamaan tempat asal usul. Dalam jaringan sosial tersebut khususnya jaringan sosial horizontal, faktor kekerabatan merupakan salah satu strategi untukmemenuhi atau mengatasi tekanan kehidupan sosial ekonomi di perkotaan. Dengan kata lain,jaringan sosial merupakan dasar untuk mempermudah akumulasi dan distribusi sumber dayasosial ekonomi yang sangat dibutuhkan oleh rumah tangga miskin.

\section{PEMBAHASAN}

\section{Pembentukan Jaringan Sosial Pasar Tiban 'Sunday Morning'}

Pembentukan jaringan dapat ditelusuri dari asal mula pedagang berjualan di pasar 'Sunmor'. Dari hasil wawancara diperoleh berbagai keterangan yang kemudian dapat disimpulkan bahwa pedagang mengetahuitentang pasar 'Sunmor' kemudian berjualan di sana karena mendapatkan infromasi dari kerabat, teman. Sebagaimana dituturkan oleh salah seorang pedagang bahwa dia mendapatkan informasi tentang pasar 'Sunmor' dari salah seorang temannya yang berjualan lebih dulu di sana. "Saya tahu Sunmor dari teman mbak, karena dia lebih dulu berjualan di sana. Trus dia ngajak saya berjualan juga", begitu penjelasan dari salah seorang pedagang. Beberapa pedagang lain memperoleh informasi tentang pasar 'Sunmor' dari kerabat yaitu dari bapak, suami atau kakak atau saudara. Disini terlihat bahwa jaringan sosial budaya berfungsi sebagai sarana adaptasi kolektif anggota keluarga terhadap tekanan-tekanan kehidupan di perkotaan. Sistem ekonomi dan kekerabatan merupakan dua unsur kebudayaan yang saling berhubungan yang satu sama lainnya saling menunjang dan tidak dapat dipisahkan. Jaringan sosial berdasarkan unsur kekerabatan mempunyai peranan yang penting dalam menghadapi tekanan sosial dan kemiskinan, pengangguran serta keterbatasan akses terhadap sumber daya ekonomi. Dengan adanya relasi dan persahabatan yang meluas kegiatan dagang dapat berjalan lebih lancar sekaligus dapat dijadikan alat untuk seseorang yang berkeinginan memasuki kegiatan sektor informal tersebut.hubungan antar kerabat dalam dunia usaha dapat juga berupa hubungan antar pemilik modal dan peminjam modal. Keuntungan akan diperoleh kedua belah pihak jika si peminjam modal bisa mengelola yang dipinjamnya. Hal ini dapat dilihat dari keterangan salah satu pedagang yang pada awalnya dia hanya membantu kakaknya berjualan di pasar 'Sunmor'. Lambat laun gaji yang terkumpul ditambah dengan modal yang diberi oleh kakaknya dia gunakan sebagai modal awal untuk membuka lapak sendiri dengan menjual aksesoris."Sekarang saya buka outlet di rumah dan berjualan di sini", demikian keterangan dari penjual aksesoris tersebut. Dari penjelasan di atas dapat disimpulkan bahwa jaringan yang terbentuk antar pedagang didasarkan pada sistem kekeluargaan atau kekerabatan atau pertemanan yang bersifat horizontal, dimana anggota-anggotanya memiliki status sosial ekonomi yang relatif sepadan. Mereka memiliki kewajiban dan sumber daya yang dipertukarkan relatif sama, hubungan sosial akan mewujudkan diri dalam bentuk tolong-menolong. Hal ini dapat dilihat misalnya dari interaksi sosial yang terjadi diantara para pedagang yang memiliki lapak yang berdekatan. Mereka seringkali tolong-menolong dalam menukar uang, membantu menjaga lapak ketika 
pemilik sedang pergi dan ada juga yang membantu melayani pembeli atau pada saat para pedagang saling bertukar sumber daya berupa infromasi mengenai tempat dimana bisa mengambil barang dagangan. Namun dalam kasus tertentu ditemukan adanya pola jaringan sosial yang didasarkan atas kekerabatan yang bersifat vertikal, yaitu antara pemilik modal dan penerima modal seperti penjual aksesoris yang mendapatkan modal dari kakaknya yang sama-sama berjualan di pasar Sunmor.

Pembentukan jaringan selanjutnya dapat dilihat dari kerjasama yang dibangun antara pedagang dan pemasok barang. Ada bermacam-macam barang yang dijual di pasar 'Sunmor' seperti menjual makanan dan minuman siap saji. Makanan yang dijual pun bermacam-macam mulai dari lontong sayur, bubur ayam , sop, soto, sate padang untuk sarapan pagi atau sekedar menjual lauk pauk seperti pepes atau ‘jajanan' seperti cireng, donat, jajan pasar. Barang-barang lain yang dijual di pasar 'Sunmor' adalah barang-barang sekunder seperti bermacam-macam baju batik, gamis, kaos, celana kolor, kerudung, peci, berbagai macam aksesoris, parfum, jam tangan, alat permainan outdor dan masih banyak lagi.

Para pedagang biasanya mengambil barang-barang dagangan dari pemasok barang seperti parfum diperoleh dari pemasok di Jakarta. Batik diperoleh pedagang dari berbagai daerah seperti Solo, Pekalongan, Yogyakarta. Adapunpenjual makanan seperti pepes ikan, bahan baku berupa ikan didapat dari penjual ikan di pasar Pandansimo dan pasar Senin. Penjual alat permainan mendapatkan bahan baku berupa kayu dari penjual kayu yang kebanyakan adalah tetangga si penjual. Hubungan antara pedagang dan pemasok barang sudah begitu dekat hingga bisa disebut langganan. Beberapa keuntungan yang didapatkan pedagang dengan mengambil barang dari pemasok yang sudah menjadi langganannya adalah mudah mendapatkan bahan baku, menguntungkan, murah, terjamin kualitas dan harganya, bisa berjualan tapi tidak keluar modal karena dagangan cuma pinjam. Pihak pemasok pun sebenarnya juga memberikan berbagai kemudahan kepada para pedagang yang sudah menjadi langganannya, misalnya saja, pemasok batik melakukan jemput bola dengan mendatangi si pedagang langganannya. Cara lain adalah meminjamkan barang dagangan seperti dagangan peci, buku dan minuman sehingga si pedagang tidak mengeluarkan modal sepeser pun. Sistem yang digunakan adalah bagi hasil untuk dagangan yang terjual, sedangkan dagangan yang tidak laku terjual bisa dikembalikan kepada pemasok. Atau bisa saja pemasok barang memberikan layanan berupa pengaturan jatuh tempo pembayaran kepada pedagang. Cara-cara seperti inilah yang kemudian bisa menumbuhkan ikatan moral yang dapat mempengaruhi hubungan ekonomi yang sedang berlangsung. Hal ini biasa terjadi pada kegiatan perdagangan di sektor informal yang menerapkan manajemen tradisional dengan memanfaatkan hubungan pertemanan, kekerabatan ataupun kedaerahan yang sangat mewarnai pengusaha yang berskala kecil. Pemasok membuat blok-blok atau jaringan pemasaran dengan tujuan untuk mempertahankan daerah pasarnya. Jaringan yang terbentuk antara pedagang dan pemasok barang merupakan jaringan sosial yang bersifat vertikal, dimana anggotaanggotanya memiliki status sosial ekonomi yang tidak sepadan, kewajiban maupun sumber daya yang dipertukarkan tidak sepadan, hubungan yang terwujud dalam bentuk hubungan patron-klien. Contoh dari 
hubungan yang bersifat vertikal dapat kita lihat dari hubungan antara penjual minuman keliling dan agen penjual. Agen penjual minuman bertindak sebagai pemilik modal sedangkan penjual minuman adalah peminjam modal. Penjual minuman akan menjual minuman dengan harga yangsudah ditentukan oleh agen. Hal serupa juga terjadi pada pedagang dan pemasok batik, peci, buku. Apabila pedagang tidak bekerjasama dengan pemasok biasanya dia akan bertindak sebagai pemasok dan pedagang sekaligus tetapi dia mempunyai buruh yang membantunya, contohnya adalah pedagang makanan siap saji.

Ada banyak strategi yang digunakan oleh para pedagang di pasar 'Sunmor' untuk mendapatkan pembeli bahkan pelanggan. Jadi konsep pelanggan disini tidak hanya berlaku antara pedagang dan pemasok barang tetapi juga antara pedagang dan pembeli. 'Pembeli yang loyal' demikian sebutan pedagang untuk pelanggan. Strategi-strategi yang digunakan oleh para pedagang untuk menjaring pelanggan adalah dalam hal menjual makanan dan minuman misalnya, mereka menjaga kualitas makanan, mempertahankan rasa masakan, halal, dengan harga yang terjangkau serta ramah dengan pembeli. Bagi para pedagang barang seperti batik, parfum, alat permainan, aksesoris mereka menerapkan strategi seperti memberikan pelayanan yang baik, memberikan kualitas barang yang bagus sesuai dengan yang ditawarkan, promosi yang menarik, memberikan potongan harga, memberikan harga yang berbeda jika pembeli 'kulakan' karena dalam beberapa kasus ada pembeli yang membeli barang dalam jumlah besar untuk kemudian dijual lagi. Hal ini dicontohkan oleh pedagang batik yang mendapatkan pembeli yang 'kulakan' batik di tempatnya.
Bagi pembeli seperti ini si pedagang akan bernegosiasi ulang untuk menentukan harga (rembugan harga). Contoh lain jika pembeli 'kulakan' parfum, pedagang akan memberikan potongan harga sebesar $\mathrm{Rp}$ 1000 dari harga normal untuk tiap botol. Jadi jika pembeli membeli parfum untuk digunakan sendiri maka akan diberikan harga Rp 5000 per botol tapi jika pembeli 'kulakan' maka akan diberikan harga $\mathrm{Rp}$ 4000 tiap botol. Contoh kasus diatas menjadi suatu model tersendiri dalam suatu jaringan pemasaran karena pada suatu waktu pedagang akan bertindak sebagai pemasok barang bagi pembeli kemudian pembeli akan bertindak sebagai pedagang. Dilihat dari tujuan hubungan sosial yang membentuk jaringan sosial dapat dilihat bahwa interaksi yang terjadi antara pedagang dan pembeli lebih kepada jaringan kepentingan (interest), dimana hubungan-hubungan sosial yang membentuknya memuat kepentingan. Kepentingan pedagang adalah menjual barang-barang dagangannya sedangkan kepentingan pembeli adalah memenuhi kebutuhannya. Ada hubungan timbal balik yang sama-sama menguntungkan diantara kedua belah pihak.

Interaksi antara pedagang dan pengurus paguyuban terjadi pada saat pasar 'Sunmo' digelar. Tiap koordinator lapangan mempunyai tugas untuk memantau situasi pasar dan menarik iuran kebersihan sebesar Rp 4000 dari tiap anggota paguyuban serta memberikan informasi kepada masingmasing anggota jika pasar akan diliburkan karena ada event tertentu. Hubungan antara pedagang dan paguyuban merupakan keteraturan hubunganstruktural,dimana pedagang bertindak sebagai anggota dan pengurus paguyuban sebagai koordinator para pedagang. Sebagaimana hubungan yang terjadi antara paguyuban dan UGM, 
dimana paguyuban bertindak sebagai wakil pengelola yang menjadi penghubung antara pedagang dan UGM sedangkan UGM adalah pengelola. Namun hubungan antara pedagang dan pengurus paguyuban tidak terlalu ketat karena ada kalanya antara paguyuban dengan anggotanya mengadakan kegiatan arisan, bakti sosial, silaturahmi. Mengacu pada kutipan Lawang (Herti, 2008 : 20) apabila dilihat dari fungsinya, maka adanya jaringan sosial antara pedagang dan paguyuban mempunyai fungsi informatif yaitu sebagai media informasi atau jaringan informasi yang memungkinkan setiap stakeholder dalam jaringan itu dapat mengetahui informasi yang berhubungan dengan masalah atau peluang apapun yang berhubungan dengan kegiatan usaha. Fungsi ini disebut juga fungsi pelumas (lubricant), fungsi peluang (opportunity) karena dengan jaringan sosial setiap peluang dapat diperoleh tanpa mengeluarkan biaya yang terlalu banyak.

Jaringan sosial yang terbentuk di pasar tiban 'Sunday Morning' dapat digambarkan sebagai berikut :

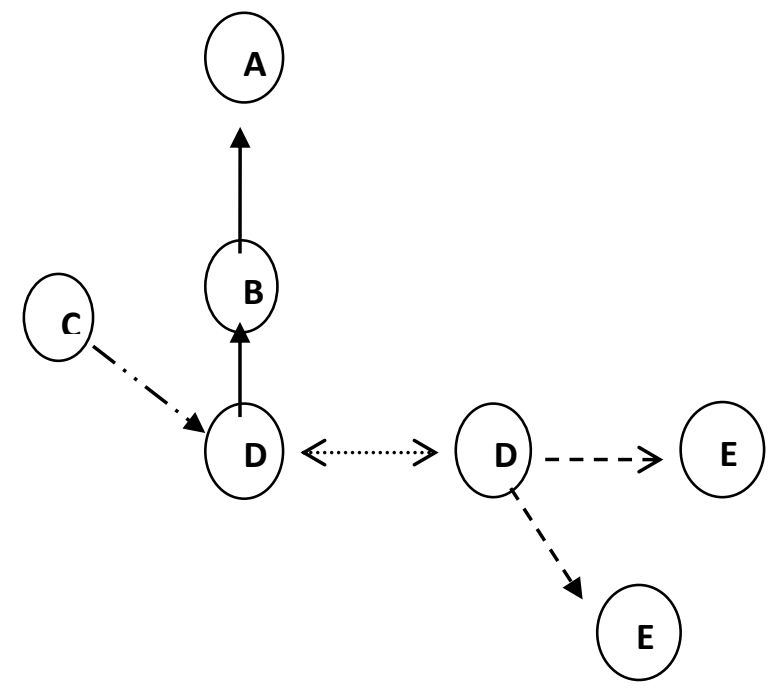

Keterangan Aktor :
A : UGM
B : Paguyuban
C : Pemasok Barang
D : Pedagang
E : Pembeli

Keterangan :

$-\cdots-\cdots$ Pemasok barang memasok barang dagangannya ke pedagang

$---\rightarrow$ Pedagang menjual barang dagangannya kepada pembeli.

-.-.- Pembeli bisa bertindak sebagai pedagang (kulakan) dan menjual barang dagangannya ke pembeli lain.

«…….... Hubungan horizontal antar sesama pedagang. Sesama pedagang saling tolong menolong, bertukar informasi.

$\longrightarrow$ Hubungan vertikal antara pedagang dengan paguyuban. Paguyuban menarik uang kebersihan, memberi informasi kepada pedagang jika pasar akan libur, memantau situasi pasar. 
Hubungan vertikal antara paguyuban dengan UGM : rapat, saling berkoordinasi antara paguyuban dan UGM.

Norma yang Berlaku dalam Jaringan Sosial

Pada sebuah jaringan sosial norma dan aturan dapat bersifat tertulis dan tidak tertulis. Perbedaan antara norma dan aturan terlihat dari sanksi yang ada jika terjadi pelanggaran oleh salah satu pihak. Sanksi dalam norma cenderung ke masalah sosial emosional, sedangkan sanksi dalam aturan cenderung lebih ke masalah ekonomi.

Beberapa aturan antara pedagang dan UGM adalah :

Lokasi berdagang sesuai dengan yang tercantum di kontrak perjanjian antara pedagang dan UGM. Ukuran-ukuran kavling juga sudah ada ketentuannya, tidak boleh menjual kavling, tidak boleh mengganggu lingkungan UGM, tidak boleh merusak tanaman, tidak boleh mengganggu ketertiban lalu lintas. Kepercayaan menjadi dasar pihak pengelola untuk membuat kesepakatan dengan pedagang, namun demikian sanksi akan diterapkan jika pedagang melanggar, misalnya tidak membayar sewa kontrak sesuai kesepakatan. Sanksi berupa teguran halus sampai pemutusan kontrak. Jika pemutusan kontrak perjanjian terjadi maka pedagang tidak akan mempunyai kesempatan lagi untuk berjualan di pasar 'Sunmor'.

Norma yang tidak tertulis dapat kita lihat dari hubungan antara pedagang dan pemasok barang. Pemasok barang kadang memberikan kelonggaran bagi pedagang untuk mengambil barang terlebih dulu bayar belakangan. Kepercayaan menjadi landasan hubungan diantara pedagang dan pemasok barang. Ikatan hutang ini telah menciptakan aturan ekonomi yang tidak tertulis antara kedua belah pihak apabila pedagang melanggar maka ia akan mendapatkan sanksi sosial tidak dipercaya lagi oleh pemasok barang. Norma yang lain dapat kita lihat dari persaingan yang tidak saling merugikan diantara para pedagang. Para pedagang sadar bahwa dalam dunia perdagangan pasti terjadi persaingan tapi mereka menyikapi persaingan dengan meningkatkan pelayanan, memberikan kualiatas barang yang bagus dan mempunyai ciri khas untuk masing-masing produk. Mereka menentukan harga yang terjangkau pembeli dan mematok harga yang sama jika ada beberapa pedagang berjualan barang dagangan yang sama.

\section{KESIMPULAN}

Keluwesan sektor informal dalam menyerap tenaga kerja bisa dikatakan sebagai salah satu keunggulan yang dimilikinya. Namun seiring dengan perkembangannya, keluwesan dan kemampuan sektor informal dalam memecahkan ketenagakerjaan ini tidak diimbangi dengan kebijakan negara untuk mengakomodasi keberadaan mereka. Pemerintah seringkali memperlakukan sektor informal layaknya "anak tiri" apabila dibandingkan dengan sektor formal namun UGM bisa menangkap fenomena ini dan kemudian mengelola menjadi suatu arena usaha yang saling menguntungkan antara berbagai pihak yang terlibat didalamnya. Pasar tiban 'Sunday Morning' justru berkembang menjadi satu tempat wisata kuliner dan belanja di Jogjakarta.

\section{DAFTAR PUSTAKA}

Badan Pusat Statistik. 2015. Keadaan Angkatan Kerja di Indonesia. Februari 2015 
Gusmiarti, Herti. 2008. Jaringan Sosial Pemetik Rumput Laut dari Alam. Studi Kasus di Desa Mancahagar Kecamatan Pameungpeuk Kabupaten Garut. Skripsi Fakultas Perikanan dan Ilmu Kelautan Institut Pertanian Bogor.

Haryono, Tri Joko S. 2007.Jaringan Sosial Migran Sirkuler. Analisis tentang Bentuk dan Fungsi.Jurnal Masyarakat, Kebudayaan dan Politik Jurusan Antropologi FISIP Universitas Airlangga Surabaya.

Hasil wawancara dengan pedagang dan pembeli di pasar Sunmor, pengurus paguyuban, pihak pengelola dari UGM.

Mitchell, J. Clyde. 1969. Social Networks in Urban Situation : Analisys of Personal Relationships in Central Africa Town. Manchester University Press.

Rini, Hartati Sulistyo. 2012. Dilema Keberadaan Sektor Informal. Jurnal Komunitas, Universitas Negeri Semarang. September.

\section{Internet :}

Bisnis.com. 05 Juli 2016 